\title{
Effect of dried Bacillus subtilis culture on growth, body composition and hepatic lipogenic enzyme activity in female broiler chicks
}

\author{
BY U.SANTOSO \\ Department of Animal Science, Faculty of Agriculture, Bengkulu University, Jln. Raya Kandang \\ Limun, Bengkulu, Indonesia \\ AND K. TANAKA* AND S. OHTANI \\ Department of Animal Science and Technology, Faculty of Agriculture, Gifu University, \\ Yanagido 1-1, Gifu 501-11, Japan
}

(Received 28 July 1994 - Revised 1 December 1994 - Accepted 16 January 1995)

To investigate the effect of dried Bacillus subtilis culture on growth, body composition and hepatic lipogenic enzyme activity, female broiler chicks were fed on either no additive (control) or dried B. subtilis-culture-supplemented commercial diets $(215 \mathrm{~g}$ crude protein/ $\mathrm{kg}, 12.85 \mathrm{MJ}$ metabolizable energy $/ \mathrm{kg}$ ) at 10 or $20 \mathrm{~g} / \mathrm{kg}$ diet for $28 \mathrm{~d}$ from 14 to $42 \mathrm{~d}$ of age. Body weight, and moisture, fat, protein and ash contents of the body were not influenced by the $B$. subtilis culture. Feed efficiency, $N$ utilization, the ratio of abdominal fat or liver to body weight, acetyl-coenzyme $A$ carboxylase $(E C 6.4 .1 .2)$ activity, liver and serum cholesterol contents were significantly lower in treatment groups, while fatty acid synthetase activity and serum cholesterol concentration were not significantly different, compared with the control group. Liver triacylglycerol concentration was decreased in chicks given $20 \mathrm{~g}$ culture $/ \mathrm{kg}$ diet, while serum and carcass triacylglycerol concentrations were significantly lower in treatment groups than in the control group. Serum phospholipid concentration was increased but carcass phospholipid concentration was decreased in chicks given $20 \mathrm{~g}$ B. subtilis/kg diet, while liver phospholipid concentration was not significantly influenced. The advantages of inclusion of $B$. subtilis to the broiler diet included improved feed efficiency, less abdominal fat, reduced triacylglycerol concentrations in the liver, serum and carcass and reduced cholesterol concentrations in the liver and carcass.

Dried Bacillus subtilis culture: Feed efficiency: Abdominal fat: Cholesterol: Triacylglycerol

Recently, investigators have become interested in the advantages of substituting microorganisms for antibiotics, because the continued use of subtherapeutic levels of antibiotics in animal feeds may result in the development of drug resistant strains of micro-organisms that are infectious to humans (Jiraphocakul et al. 1990). Moreover, increases in carcass fat and cholesterol contents of modern broiler chickens continue to be a health concern of consumers. In addition, abdominal and visceral fat are waste products to the poultry processor and add to waste management problems. Furthermore, accumulation of triacylglycerol in the liver results in fatty liver in broiler chicks.

Pertaining to these problems, recent investigations have shown that the inclusion of micro-organisms in animal diets prevents diarrhoea (Sissons, 1989), reduces serum cholesterol (Danielson et al. 1989; Imaizumi et al. 1992), reduces body fat (Chah et al. 1975), and improves growth and feed efficiency (Chah et al. 1975; Goodling et al. 1987; Jiraphocakul et al. 1990). There have been few investigations of the effects of B. subtilis

\footnotetext{
* For reprints.
} 
Table 1. Composition of the experimental diets $(\mathrm{g} / \mathrm{kg} \text { diet })^{*}$

\begin{tabular}{lccc}
\hline \hline & & \multicolumn{2}{c}{$\begin{array}{c}\text { Bacillus subtilis } \\
\text { supplemented }\end{array}$} \\
\cline { 3 - 4 } & Control & $+10 \mathrm{~g}$ & $+20 \mathrm{~g}$ \\
\hline Moisture & 126 & 123 & 122 \\
Protein & 215 & 218 & 224 \\
Fat & 59 & 59 & 59 \\
Fibre & 50 & 50 & 50 \\
Ash & 80 & 80 & 80 \\
Nitrogen-free extract & $\mathbf{4 7 0}$ & $\mathbf{4 7 0}$ & 465 \\
\hline
\end{tabular}

* All variables were analysed four times.

$\dagger$ Nitrogen-free extract $=1000-($ moisture + protein + fat + fibre + ash $)$.

culture in poultry. Therefore, the present study was conducted to evaluate the effect of a dried $B$. subtilis culture added to the diet on growth, body composition, lipogenic enzyme activities and various lipid fractions in liver, serum and carcass of broiler chicks.

\section{MATERIALS AND METHODS}

\section{Animals and diets}

Thirty 1-d-old female broiler chicks (Chunky) were raised in individual wire-floor cages and fed on a commercial starter diet with no antibiotics included ( $215 \mathrm{~g}$ crude protein $/ \mathrm{kg}$, $12.85 \mathrm{MJ}$ metabolizable energy $/ \mathrm{kg}$ ). Feed and water were provided ad lib. House temperature was maintained at $25 \pm 3^{\circ}$ with a photoperiod of $14 \mathrm{~h}$. At $14 \mathrm{~d}$ of age, female broiler chicks were weighed individually and divided into three treatment groups. One group was a control with no additive, and two treatment groups were given the commercial diet supplemented with 10 or $20 \mathrm{~g}$ dried $B$. subtilis culture $/ \mathrm{kg}$. The composition of the experimental diets after inclusion of the dried $B$. subtilis culture is presented in Table 1. Broilers were weighed individually on a weekly basis, and feed consumption was recorded daily.

\section{General procedure}

At $42 \mathrm{~d}$ of age, five female broiler chicks from each group were killed by decapitation and abdominal fat and liver were immediately removed and weighed. A $4 \mathrm{~g}$ portion of each liver was flushed with ice-cold saline $(9 \mathrm{~g} \mathrm{NaCl} / \mathrm{l})$ before assessment of lipogenic enzyme activity, and another $4 \mathrm{~g}$ portion was used for analysis of various lipid fractions; the remainder was returned to the carcass. The carcasses (the body without digestive contents and feathers) were minced five times to obtain uniform mixing.

The various lipid fractions were separated by thin-layer chromatography on silica-gel chromarods using hexane-diethyl ether-formic acid $(60: 10: 0 \cdot 1$, by vol.) and hexanebenzene $(1: 1, \mathrm{v} / \mathrm{v})$ as developing solvents, and quantified using an Iatroscan TH-10 TLC/FID Analyser (Iatron Laboratories Inc., Tokyo, Japan) (Tanaka et al. 1979). Carcass composition was determined by the method of the Association of Official Analytical Chemists (1980). For measuring nutrient utilization, faeces from five chicks of each group were collected 1 week before the experiment finished. Each sample was analysed three times, and results were accepted if the within-sample differences were less than $1 \%$. 


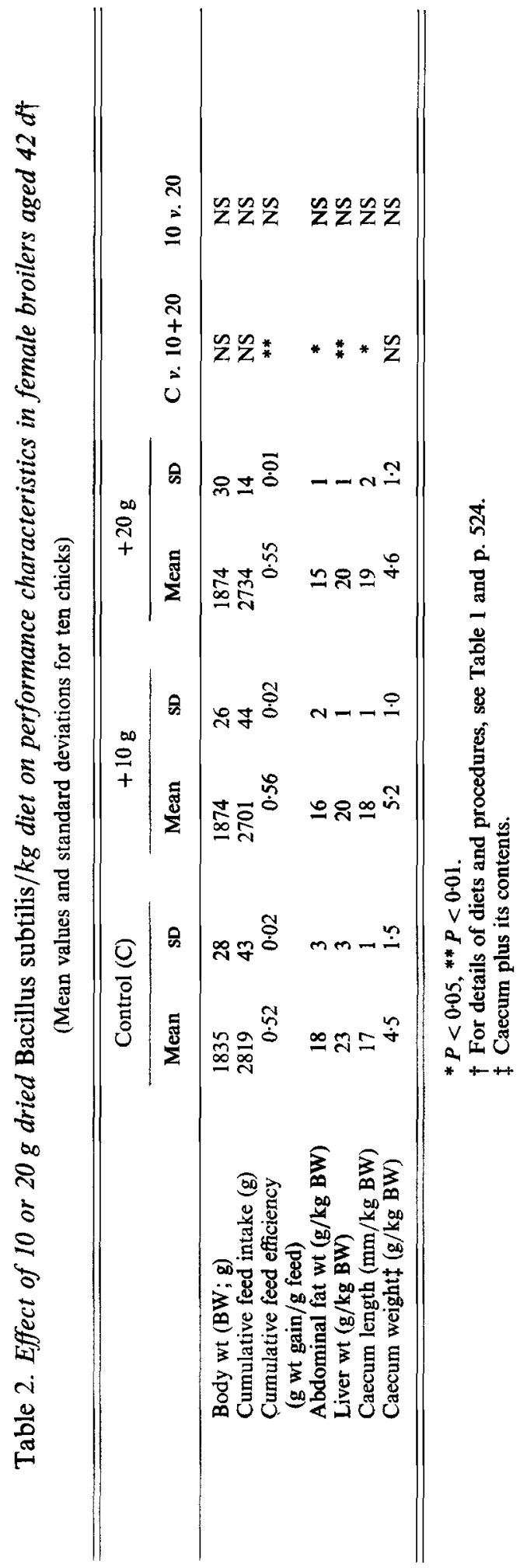


Table 3. Effects of 10 or $20 \mathrm{~g}$ Bacillus subtilis culture $/ \mathrm{kg}$ diet on body composition $\left(\mathrm{g} / \mathrm{kg}\right.$ carcass weight) and nutrient utilization $(\mathrm{g} / \mathrm{g})$ in female broilers aged $42 d^{\dagger}$

(Mean values and standard deviations for five chicks)

\begin{tabular}{|c|c|c|c|c|c|c|c|c|}
\hline & \multicolumn{2}{|c|}{ Control (C) } & \multicolumn{2}{|c|}{$+10 \mathrm{~g}$} & \multicolumn{2}{|c|}{$+20 \mathrm{~g}$} & \multirow{2}{*}{$\begin{array}{c}C v . \\
10+20\end{array}$} & \multirow{2}{*}{$\begin{array}{c}10 v \\
20\end{array}$} \\
\hline & Mean & $\mathrm{SD}$ & Mean & $\mathrm{SD}$ & Mean & $\mathrm{SD}$ & & \\
\hline Moisture & 652 & 11 & 663 & 8 & 670 & 5 & NS & NS \\
\hline Protein & 164 & 7 & 162 & 6 & 163 & 6 & NS & NS \\
\hline Fat & 145 & 16 & 137 & 9 & 134 & 6 & NS & NS \\
\hline Ash & 39 & 6 & 38 & 4 & 33 & 2 & NS & NS \\
\hline \multicolumn{9}{|c|}{ Nutrient utilization } \\
\hline Dry matter & 0.73 & 0.02 & 0.73 & $0 \cdot 01$ & 0.73 & 0.02 & NS & NS \\
\hline Fat & 0.81 & 0.02 & 0.81 & $0 \cdot 01$ & 0.82 & 0.01 & NS & NS \\
\hline Nitrogen & 0.56 & 0.02 & 0.59 & $0 \cdot 01$ & 0.58 & 0.01 & $*$ & NS \\
\hline
\end{tabular}

$* P<0.05$.

$\uparrow$ For details of diets and procedures, see Table 1 and p. 524.

Table 4. Effects of 10 or $20 \mathrm{~g}$ Bacillus subtilis $/ \mathrm{kg}$ diet on lipogenic enzyme activity ( $n$ mol/min per $m g$ protein $\dagger$ ) in female broilers aged $42 d \ddagger$

(Mean values and standard deviations for five chicks)

\begin{tabular}{|c|c|c|c|c|c|c|c|c|}
\hline & \multicolumn{2}{|c|}{ Control (C) } & \multicolumn{2}{|c|}{$+10 \mathrm{~g}$} & \multicolumn{2}{|c|}{$+20 \mathrm{~g}$} & \multirow{2}{*}{$\begin{array}{c}C v . \\
10+20\end{array}$} & \multirow{2}{*}{$\begin{array}{c}10 v \\
20\end{array}$} \\
\hline & Mean & SD & Mean & SD & Mean & $\mathrm{SD}$ & & \\
\hline $\begin{array}{l}\text { Acetyl-CoA carboxylase } \\
(E C 6.4 .1 .2)\end{array}$ & 0.232 & $0 \cdot 020$ & 0.223 & 0.014 & 0.197 & 0.014 & $*$ & * \\
\hline Fatty acid synthetase & $4 \cdot 26$ & $0 \cdot 77$ & $4 \cdot 78$ & 0.65 & 3.94 & 0.45 & NS & NS \\
\hline
\end{tabular}

* $P<0.05$.

$\dagger$ Enzyme activities are expressed as nmol substrate converted to product/min per mg protein at $37^{\circ}$.

$\$$ For details of diets and procedures, see Table 1 and pp. 524-526.

\section{Enzyme assay}

Livers were homogenized in $\mathbf{0 . 2 5} \mathrm{M}$-sucrose solution containing $1 \mathrm{mM}-\mathrm{EDTA}-2 \mathrm{Na}$, after which the homogenates were centrifuged at $600 \mathrm{~g}$ at $4^{\circ}$ for $10 \mathrm{~min}$. The supernatant fractions were recentrifuged at $105000 \mathrm{~g}$ at $4^{\circ}$ for $60 \mathrm{~min}$ and the resulting clear supernatant fractions (cytosolic fraction) were used for assaying lipogenic enzymes. Acetyl-CoA carboxylase ( $E C$ 6.4.1.2) activity was assayed by a $\mathrm{H}^{14} \mathrm{CO}_{3}$-fixation method (Qureshi et al. $1980)$. Fatty acid synthetase activity was assayed by the $\left[1-{ }^{14} \mathrm{C}\right] \mathrm{CoA}$ incorporation method (Hsu et al. 1965). The protein content of the solution used for each enzyme assay was determined by the method of Lowry et al. (1951) using bovine serum albumin as the standard. Enzyme activities are expressed as nmol substrate converted to product/min per mg protein at $37^{\circ}$.

\section{Statistical analyses}

Treatment effects were assessed for all response variables using one-way ANOVA in which the overall treatment differences were represented by two orthogonal contrasts: (1) control $v$. supplement and (2) low v. high levels of supplementation. Differences were considered statistically significant at the $5 \%$ level. Where appropriate, regression analysis was used to assess the statistical significance of the correlation between variables. 
Table 5. Effects of 10 or $20 \mathrm{~g}$ Bacillus subtilis culture $/ \mathrm{kg}$ diet on lipid fractions in the liver, serum and carcass of broiler chicks aged $42 d^{\dagger}$

(Mean values and standard deviations for five chicks)

\begin{tabular}{|c|c|c|c|c|c|c|c|c|}
\hline & \multicolumn{2}{|c|}{ Control (C) } & \multicolumn{2}{|c|}{$+10 \mathrm{~g}$} & \multicolumn{2}{|c|}{$+20 \mathrm{~g}$} & \multirow{2}{*}{$\begin{array}{c}C v . \\
10+20\end{array}$} & \multirow{2}{*}{$\begin{array}{c}10 v \\
20\end{array}$} \\
\hline & Mean & SD & Mean & SD & Mean & SD & & \\
\hline \multicolumn{9}{|l|}{ Liver $(\mathrm{mg} / \mathrm{g})$} \\
\hline Triacylglycerol & $21 \cdot 6$ & $5 \cdot 6$ & $18 \cdot 9$ & $4 \cdot 1$ & $12 \cdot 6$ & $3 \cdot 2$ & $* *$ & $*$ \\
\hline Total cholesterol & 3.4 & 0.2 & $3 \cdot 2$ & $0 \cdot 1$ & $3 \cdot 1$ & 0.1 & * & NS \\
\hline Phospholipid & $9 \cdot 4$ & 0.6 & $10 \cdot 6$ & 0.3 & $9 \cdot 3$ & 0.4 & NS & NS \\
\hline \multicolumn{9}{|l|}{ Serum (mmol/l) } \\
\hline Triacylglycerol & 0.39 & 0.07 & 0.29 & 0.05 & 0.32 & 0.04 & * & NS \\
\hline Total cholesterol & $4 \cdot 62$ & 0.15 & $4 \cdot 60$ & $0 \cdot 22$ & $4 \cdot 33$ & 0.15 & NS & NS \\
\hline Phospholipid (mg/l) & 965 & 70 & 924 & 99 & 1738 & 103 & $* *$ & $* *$ \\
\hline \multicolumn{9}{|l|}{ Carcass (mg/g) } \\
\hline Triacylglycerol & $9 \cdot 9$ & $2 \cdot 0$ & 6.7 & $1 \cdot 1$ & 6.6 & 0.5 & ** & NS \\
\hline Total cholesterol & $2 \cdot 2$ & $0 \cdot 2$ & $1 \cdot 8$ & $0 \cdot 1$ & $1 \cdot 5$ & $0 \cdot 1$ & $* *$ & NS \\
\hline Phospholipid & 0.7 & 0.2 & 0.7 & 0.05 & 0.3 & 0.1 & $* *$ & $* *$ \\
\hline
\end{tabular}

* $P<0.05, * * P<0.01$.

$\dagger$ For details of diets and procedures, see Table 1 and p. 524.

\section{RESULTS}

Growth performance study

As shown in Table 2, statistically significant differences were not seen in body weight, feed intake and caecum weight among the groups. An improved feed efficiency was observed in the 10 and $20 \mathrm{~g} \mathrm{~B}$. subtilis-supplemented groups compared with control chicks $(P<0.01)$. The ratios of liver and abdominal fat to body weight were significantly decreased in treatment groups, compared with the control. Caecum lengths of broiler chicks given 10 or $20 \mathrm{~g} \mathrm{~B}$. subtilis were significantly greater than those of control chicks.

\section{Body composition and nutrient utilization}

None of the groups exhibited any changes in body moisture, protein, fat, ash, dry matter or fat utilization (Table 3). A significantly improved $\mathrm{N}$ utilization was observed in chicks given 10 or $20 \mathrm{~g} \mathrm{~B}$. subtilis $/ \mathrm{kg}$ diet, compared with the control.

\section{Hepatic lipogenic enzyme activities}

Hepatic acetyl-CoA carboxylase activity was significantly reduced when $20 \mathrm{~g}$ dried $B$. subtilis culture $/ \mathrm{kg}$ was added to the diet (Table 4). Fatty acid synthetase activity, however, was not significantly different.

\section{Lipid fractions study}

The effects of dried $B$. subtilis culture on liver, serum and carcass lipid fractions are presented in Table 5 . The liver triacylglycerol concentration was significantly reduced in $20 \mathrm{~g} / \mathrm{kg} \mathrm{B}$. subtilis-culture-fed chicks, compared with other groups. Triacylglycerol concentrations in the serum and carcass were significantly reduced in the treatment groups compared with the controls. Cholesterol concentrations in the liver and carcass were significantly reduced in the treatment groups, compared with the control, whereas those in 
the serum were not significantly different. In the present study dried $B$. subtilis culture did not influence liver phospholipids. However, broiler chicks given $20 \mathrm{~g} \mathrm{~B}$. subtilis culture/kg diet had higher levels of serum phospholipids and lower levels of carcass phospholipids.

\section{DISCUSSION}

The purpose of the present experiment was to determine the advantages of dried $B$. subtilis culture on growth performance, body composition and lipid metabolism in broiler chicks. Broilers receiving the bacterial culture showed slightly greater weight gain and significantly improved feed efficiency. Similar results have been obtained using calves (Jenny et al. 1991) and turkeys (Jiraphocakul et al. 1990). Continuous feeding of B. subtilis to animals provides a constant inoculation of the organism in the alimentary tract (Jiraphocakul et al. 1990). Furthermore, this organism may associate with the gut wall and favour an increase in numbers of natural lactobacilli, which, in turn, will suppress the growth of undesirable enteric micro-organisms such as Escherichia coli, thus improving feed efficiency.

The effect of $B$. subtilis culture supplementation was more pronounced in decreasing abdominal fat than body fat content. It has been suggested that considerable changes in abdominal fat sometimes occur without large changes in body fat (Ricard et al. 1983). The decreased acetyl-CoA carboxylase activity observed in the present study may partly explain the decreased abdominal fat observed in the treatment groups (Hasegawa et al. 1994). This was confirmed by the regression analysis (Table 6). Decreased abdominal fat would constitute an important advantage in broiler production, because this fat is a waste product to the poultry processor and adds to waste management problems. It is of interest to note that there was a relationship between body fat content and caecum length, feed efficiency and body weight (Table 6). It is generally accepted that there is a relationship between body fat and body moisture, and between abdominal fat and body fat. The present study confirms this view.

In the present study $B$. subtilis culture influenced fatty acid synthesis in the liver of female broilers as indicated by a decrease in the activity of acetyl-CoA carboxylase, the rate limiting enzyme in fatty acid synthesis. Decreased fatty acid synthesis is of major importance for the triacylglycerol-lowering effect (Skorve et al. 1993). Thus, it is not surprising that liver, serum and carcass triacylglycerol concentrations were decreased. A

Table 6. Regression analysis results

(Observations from fifteen chicks)

\begin{tabular}{llrrrr}
\hline \multicolumn{1}{c}{$\boldsymbol{c} y$} & \multicolumn{1}{c}{$\boldsymbol{a}$} & \multicolumn{1}{c}{$b$} & $r^{2}$ & $P$ \\
\hline Body moisture & Body fat & 1.175 & -0.005 & 0.998 & $<0.01$ \\
Body fat & Caecum length & 4.159 & -0.170 & 0.9356 & $<0.01$ \\
Body fat & ACC & 0.148 & +0.004 & 0.998 & $<0.01$ \\
Body fat & Abdominal fat & -2.084 & +0.268 & 0.996 & $<0.01$ \\
Body fat & Feed efficiency & 0.987 & -0.032 & 0.762 & $<0.01$ \\
Body weight & Body fat & 59.198 & $-\mathbf{0 . 0 2 4}$ & $\mathbf{0 . 9 3 0}$ & $<0.01$ \\
Liver TG & Serum TG & $\mathbf{1 3 . 8 2 1}$ & $+\mathbf{+ 0 . 8 9 0}$ & $\mathbf{0 . 8 1 1}$ & $<\mathbf{0 . 0 1}$ \\
Liver TG & Carcass TG & $\mathbf{2 . 3 4 4}$ & $\mathbf{+ 0 . 3 0 5}$ & $\mathbf{0 . 5 6 1}$ & $<0.05$ \\
Liver FC & Serum FC & 71.464 & +31.929 & 0.627 & $<0.05$ \\
Liver FC & Carcass FC & -5.557 & +2.286 & 0.988 & $<0.01$ \\
Abdominal fat & ACC & -0.165 & +0.028 & 0.762 & $<0.01$ \\
Liver weight & Liver TG & -23.250 & +19.500 & 0.535 & $<0.05$ \\
\hline \hline
\end{tabular}

ACC, acetyl CoA carboxylase (EC 6,4 1.2) activity; TG, triacylglycerol; FC, free cholesterol. 
reduction in hepatic triacylglycerol concentration is known to be beneficial for chicks, inhibiting the development of fatty liver, whilst a lower triacylglycerol content in the carcass would result in a healthier meat for the consumer. Our results also indicate that $B$. subtilis might have anticholesterolaemic properties. It is unclear, however, by which mechanism B. subtilis culture decreases the cholesterol concentration. Youn et al. (1993) stated that there was a positive relationship between the activity of hepatic 3-hydroxy-3methylglutaryl (HMG)-coenzyme A reductase $(E C 1.1 .1 .88)$, the rate limiting enzyme of cholesterogenesis, and the hepatic cholesterol content of growing chicks. Therefore, reduced hepatic cholesterol synthesis may be one of the factors contributing to the decreased liver cholesterol concentration. A lower cholesterol concentration in the liver would result in less cholesterol in the serum and carcass (Table 6). In the present study there was also a relationship between liver triacylglycerol and serum triacylglycerol or carcass triacylglycerol (Table 6). Inclusion of $20 \mathrm{~g} \mathrm{~B}$. subtilis $/ \mathrm{kg}$ diet increased the serum phospholipid concentration and decreased carcass phospholipid, but it did not affect liver phospholipid. It is difficult from the present study to discuss this result. It would be logical to conclude that dried $B$. subtilis culture added to the broiler diet had a beneficial impact on broiler production and consumer health.

\section{REFERENCES}

Association of Official Analytical Chemists (1980). Official Methods of Analysis, 13th ed. Washington: Association of Official Analytical Chemists.

Chah, C. C., Carlson, C. W., Semeniuk, G., Palmer, I. S. \& Hesseltine, C. W. (1975). Growth-promoting effects of fermented soybean for broilers. Poultry Science 54, 600-609.

Danielson, A. D., Peo, E. P. Jr, Shahani, K. M., Lewis, A. J., Whalen, P. J. \& Amer, M. A. (1989). Anticholesteremic property of Lactobacillus acidophilus yogurt fed to mature boars. Journal of Animal Science 67, 966-974.

Goodling, A. C., Cerniglia, G. J. \& Hebert, J. A. (1987). Production performance of White Leghorn layers fed Lactobacillus fermentation products. Poultry Science 66, 480-486.

Hasegawa, S., Hatano, S., Ushima, K. \& Hikami, Y. (1994). Effect of fasting on adipose tissue accumulation in chicks, with reference to change in its chemical composition and lipase activity. Animal Science and Technology (Japan) 65, 89-98.

Hsu, R. Y., Wasson, G. \& Porter, J. W. (1965). The purification and properties of the fatty acid synthetase of pigeon liver. Journal of Biological Chemistry 240, 3736-3746.

Imaizumi, K., Hirata, K., Zommara, M., Sugano, M. \& Suzuki, Y. (1992). Effects of cultured milk products by Lactobacillus and Bifidobacterium species on the secretion of bile acids in hepatocytes and in rats. Journal of Nutritional Science and Vitaminology 38, 343-351.

Jenny, B. F., Vandijk, H. J. \& Collins, J. A. (1991). Performance and fecal flora of calves fed a Bacillus subtilis concentrate. Journal of Dairy Science 74, 1968-1973.

Jiraphocakul, S., Sullivan, T. W. \& Shahani, K. M. (1990). Influence of dried Bacillus subtilis culture and antibiotics on performance and intestinal microflora in turkeys. Poultry Science 69, 1966-1973.

Lowry, O. H., Rosebrough, N. J., Farr, A. L. \& Randall, R. J. (1951). Protein measurement with the Folin phenol reagent. Journal of Biological Chemistry 193, 265-275.

Qureshi, A. A., Burger, W. C., Prentice, N., Bird, H. R. \& Sunde, M. L. (1980). Regulation of lipid metabolism in chicken liver by dietary cereals. Journal of Nutrition 110, 388-393.

Ricard, F. H., Leclerq, B. \& Toraille, C. (1983). Selecting broilers for low or high abdominal fat: distribution of carcass fat and quality of meat. British Poultry Science 24, 511-516.

Skorve, J., al-Shurbaji, A., Asiedu, D., Björkhem, I., Berglund, L. \& Berge, R. K. (1993). On the mechanism of the hypolipidemic effect of sulfur-substituted hexadecanedioic acid (3-thiadicarboxylic acid) in normolipidemic rats. Journal of Lipid Research 34, 1177-1185.

Sissons, J. W. (1989). Potential of probiotic organism to prevent diarrhoea and promote digestion in farm animals - a review. Journal of the Science of Food and Agriculture 49, 1-13.

Tanaka, K., Ohtani, S. \& Shigeno, K. (1979). Effects of dietary protein level on lipid metabolism. Japanese Journal of Zootechnical Science 50, 44-54.

Youn, B. S., Tanaka, K., Ohtani, S. \& Santoso, U. (1993). The effect of dietary fats on the hepatic and intestinal 3-hydroxy-3-methyl-glutaryl coenzyme A reductase activities in chicks. Asian-Australasian Journal of Animal Science 6, 281-290. 